\title{
EFFECTS OF THE DECISIONS OF SAN REMO CONFERENCE ON SYRIA AND IRAQ
}

\author{
Resul Yavuz*
}

\begin{abstract}
After the end of the First World War, many negotiations between the Allies were held since December of 1918, in the course of sharing of the Middle East and establishing new states. In January 1919, during the Paris Peace Conference where the post-war new world order would discuss, the way of the establishment of the states in Syria and Iraq was put on the agenda. However, when it was taken account of the British declaration of establishing a Jewish settlement in Palestine in the Balfour Declaration in 1917, it was not possible to preserve the peace in Arab lands. The British and the French were faced with intense reactions in the process of implementing the decisions of the San Remo Conference which was held in April 1920 to shape the peace treaty with Ottoman State, in Syria, Palestine and Iraq. Besides, as a result of BritishFrench negotiations which started in 1919 and concentrated during 1920, the withdrawal of British from Syria for the benefits of France disappointed Sheriff Hussein and his son Faisal, this caused new uncertainties for the region. Hence, the expulsion of Faisal from Syria after the Battle of Maysalun in July, 1920 began to disturb the British. Britain helped Faisal to become the king of Iraq and had a green light to his brother Abdullah to become king in Jordan in order to prevent them as an impediment in Cairo Conference in March 1921. Despite all the arrangements, the British and French mandate regimes faced with serious difficulties in the process of establishing full control in Arab lands while trying to keep their sovereignty.
\end{abstract}

Key Words: Syria, France, Great Britain, Iraq, Battle of Maysalun

Öz

San Remo Konferansı Kararlarının Suriye ve Irak Üzerindeki Etkileri

Birinci Dünya Savaşı'nın sona ermesinden sonra Ortadoğu'nun paylaşımı ve burada yeni devletlerin ihdas edilmesi aşamasında, 1918 yılının Aralık ayından itibaren Müttefikler arasında birçok görüşmeler gerçekleştirilmişti. Ocak 1919'da savaş sonrası yeni dünya düzeninin konuşulacağı Paris Barış Konferansın'daki görüşmeler trafiğinde, Suriye ve Irak'ta kurulması planlanan devletlerin ne şekilde oluşturulacağı da gündeme alınmıştı. Ancak 1917 yılında yayımlanan Balfour Deklerasyonu'nda İngilizlerin Yahudilere Filistin'de bir yerleşim yeri

\footnotetext{
* Ph.D., Turkish Ministry of National Education, Ankara. E-mail: resulyavuz@hotmail.com (Makale Gönderim Tarihi: 04.10.2017 - Makale Kabul Tarihi: 22.11.2017)
} 
kurulması sözünün vermesi de hesaba katıldığında, savaştan sonra Arap toprakları üzerinde barışın egemen olması mümkün olamamıştı. Özellikle Nisan 1920 yılında toplanan ve Osmanlı Devleti ile imza edilecek barış antlaşmasına son şeklin verileceği San Remo Konferansı'nda alınan kararlarının Suriye, Filistin ve Irak'ta uygulanmaya çalışılması aşamasında, İngiliz ve Fransızlar yoğun tepkilerle karşı karşıya kalmışlardı. Ayrıca 1919 yılında başlayan ve 1920 yılı içerisinde iyice yoğunlaşan İngiliz-Fransız görüşmeleri neticesinde, İngiltere'nin çıkarları gereği Suriye'den Fransa lehine çekilmesi, Şerif Hüseyin ve oğlu Faysal'ı hayal kırıklığına uğratmış, bölge için yeni belirsizliklerin zuhur edeceği bir süreci başlatmıştır. Nitekim Fransa'nın Temmuz 1920'deki Maysalon Savaşı'ndan sonra Faysal'ın Şam'dan kovulması İngiliz Yönetimini tedirgin etmeye başlamıştı. İngiltere, Faysal'ın kendilerine daha fazla ayak bağı olmaması için Mart 1921'de toplanan Kahire Konferansı ile kendisinin Irak'a kral olmasını sağlarken, kardeşi Abdullah'ın da oluşturulacak olan Ürdün'e kral olmasına yeşil ışık yakmıştı. Ancak bütün bu düzenlemelere rağmen İngiliz ve Fransız manda yönetimleri egemenliklerini sağlamaya çalıştıkları Arap topraklarında düzeni tam olarak tesis etmeleri aşamasında büyük ve ciddi sıkıntılarla karşılaşmışlardır.

Anahtar Kelimeler: Suriye, Fransa, Ingiltere, Irak, Maysalon Savaşı

\section{Introduction}

Ottoman State's being defeated in the World War I left an indelible impression on the Middle Eastern geography and became the beginning of a long-running period of which influence would last until the present day. Immediately after the Ottomans surrendered to the British attending the talks representing the Allies under an armistice of twenty-five articles, namely Armistice of Mudros, on the Island Lemnos, the Allies started to occupy Anatolia by trespassing the boundaries determined by the armistice in so short a time while they had been involved in reckonings of partition on the territories which got out of hand during the years of war in the light of the promises made earlier. Such reckonings started to lead to conflicts at the diplomatic level both between the Allies and among such elements as Arabs, Jews, Armenians and Kurds having great expectations from the Allies with the hope of founding their own states.

Allies signed several secret treaties for dividing the Ottoman State among themselves even during the years of war. It is doubtless that the Sykes-Picot Agreement which the British and Frenchmen signed upon a short infrastructural study for partitioning the Middle East has been one of the partition agreements which made a name for itself despite more than a hundred years has passed since the day when it was signed. Although the agreement went under some modifications as it did not comply with the deep strategic plans and expectations of the British authorities in the Middle East after the war, it continuously came to be known for its initial form and the name of this agreement always was referred to on a great many maps containing the division of the Middle East. According to the Sykes-Picot Agreement which took its final form on $23^{\text {rd }}$ October 1916 with the parties' wishes as to include the 
Czarist Russia, Adana, Antakya region, Syrian coasts, and Lebanon would be left to France; Iraq, excluding Mosul, to Great Britain. A great Arab kingdom would be founded to include the other regions of Syria, Mosul, and Jordan under the British and French auspices ${ }^{1}$. As from the date when this secret agreement which would take its final form upon an agreement to be signed with Russia, each provision would lead to deep arguments containing the signing parties before, so to speak, the ink on it dried up. Particularly, when Sharif Hussein, who took part with the Allies with a promise of freedom, became aware of the existence of the agreement, he would give a strong reaction to the agreement and send his son Faisal to London and Paris in order to hold diplomatic talks for the modification of the provisions thereof after the war. In fact, just when the British and French diplomats started to divide the Middle East into their own spheres of influence, the rebellious Arabs under the command of Sharif Hussein were in a rush to make future plans on the Middle East territories by making some attempts with Great Britain.

Undoubtedly, we see the first example of this in the words used in the anonymous letter sent to McMahon, Great Britain’s High Commissioner, who had his office in Cairo, on $14^{\text {th }}$ July 1915 by Sharif Hussein. In this first letter to the British government, Sharif Hussein claimed almost all of the Arab Peninsula between the Persian Gulf and the Red Sea and the part of Eastern Anatolia possessing the ports to the South down from the Taurus Mountains in the North as a condition for their taking sides with the British in the war. $37^{\text {th }}$ parallel started in the north of Muğla in the west and passed through Antalya, Adana, and Gaziantep and continued towards the border with Iran. And Sharif Hussein also wanted the eastern part where Arabic was not spoken and the ports of Mersin and Iskenderun (Alexandretta) to be given to him. This claim made in a period when the Sykes-Picot Agreement had not yet been signed coincided with a period in which things did not go well for the Allies at Çanakkale and the Iraqi Front. In fact, the British government needed an ally who would make things difficult for the Turks at Hejaz and the whole Middle East ${ }^{2}$.When McMahon replied this letter of Sharif Hussein on August 30, 1915, correspondence continued between the British government and Sharif Hussein until the middle

\footnotetext{
${ }^{1}$ Uçarol, 1995, p. 495; The agreement which was much spoken of afterwards was declared an unwanted child especially by the British and Arab sides. While Lloyd George, who wrote his memoirs afterwards considered the agreement to be a stupid document, Lord Curzon used harsher statements and said that those who signed the agreement drew it as a fantastic picture which showed a situation which did not exist at that time. Lazarev, 1989, p. 51.

${ }^{2}$ Köse, 2014, p. 143.
} 
of 1916 and laid the ground for an Arab revolt against the Ottoman State ${ }^{3}$.When the Arab revolt which well flamed up upon the McMahon Agreement and which contained several British intelligence officers like Lawrence as provokers started at Hejaz and expanded towards Syria and Jordan, the Ottoman Army would be up against the wall and the governmental agencies would fail to suppress the revolt despite all efforts. Eventually, Sharif Hussein Revolt provoked by Great Britain would cost a lot for the Ottoman State and, considering the achievements of the Allies at the other fronts towards the end of the war, the Ottoman Government would lose command almost all over the Middle East.

The British were in contact with the Zionist Government for the allocation of a settlement for the Jews in Palestine as if they cracked the door open for new problems of which effects would continue until the present day on the Middle East territories in 1917, when the war still continued and the winning party had not yet been identified. In fact, even since the beginning of the war, the World Zionist Organisation had been continuously making attempts for getting results in order to achieve such goal in several cities throughout Europe, including London. Eventually, at the end of profound attempts, the official declaration of the British Foreign Ministry which was written to Lord Rothschild on the foundation of a Jewish State on the Palestine territories in June 1917 by the British Foreign Secretary Arthur Balfour and which later became famous as "Balfour Declaration" would be released ${ }^{4}$.This document which was considered the title deed of the Israeli State by the Zionist organizations ${ }^{5}$ fell like a bomb into the complicated agenda of the Middle East when the war was over and was considered to be a significant stage in the accomplishment of the dreams of the Zionists to found a state in Palestine besides the reckonings of the Allies and their promises to the Arabs. After such date, Zionists would start to raise their voice at least as high as the Arabs with a tone increasing from day to day with this historical document declared by the British Government.

Considering the promises made to both Arabs and Israelis besides the partition plans made among themselves by the Allies, the Allies gradually started to understand that they had messed up the things in the Middle East towards the end of the war. In fact, developments occurring in both diplomatic -

${ }^{3}$ For detailed information on the content of the correspondence between Sharif Hussein and McMahon, see. Köse, 2014, pp. 80-157.

${ }^{4}$ Öke, 2011, pp. 244-245; For detailed information on the efforts of diplomacy implemented during the preparation of the Balfour Declaration and the origins of the Arab-Israeli conflict, see. Schneer, 2011.

${ }^{5}$ Öke, 2011, pp. 244-245; 
including Czarist Russia's withdrawal from the war and seizing of the government by Bolsheviks - and military spheres during 1918 which was the last year of the war caused the parties to become aware of the leverage in each other's hands once the secret negotiations made for the Middle East had been revealed. In the Middle East where all reckonings were planned for overwhelming the Ottoman State, secret negotiations, strategic agreements, and promises made for the promised territories had become well contradictory in a period of time when the war was going to an end. At the first stage, Great Britain deemed it necessary to make some diplomatic manoeuvres immediately in order to obviate such a chaos among her own allies with whom she had entered the war. For this purpose, once Czarist Russia had withdrawn from the war and Russia had waived from the secret agreements, the British Government deemed it necessary to release the Hogarth Message in order to secure the goodwill of the Arabs and show that the Balfour Declaration would not prejudice the Arab freedom in January 1918. Great Britain released his message ${ }^{6}$ in which it was especially stated that "Balfour Declaration shall be applied as long as it is consistent with the economic and political freedoms of the population living in the region..."'in order to alleviate the shocking impact of Russia's withdrawal from the war and secret agreement for the partition of the Middle East between the Allies on the Arabs. The British Government had to release the "Declaration to the Seven" entirely addressed to the Arab leaders in order not to lose the support of the Arabs in June 1918 in a period when the US Government prepared to get involved in the partition policies through the Wilson Principles which they had released to apply at the end of the war. In the declaration, the British Government accepted the seven Arab leaders as the "leaders of the sovereign and free Arabs" who were free before the war or who lived in the regions recovered from the Turks during the war. The attention of the US Government was drawn by further emphasizing that the partition and government of the regions occupied by the Allies or controlled by the Turks would be handled in accordance with the "consent of the governed principle" as described in the Wilson's Points ${ }^{7}$.

When the Paris Peace Conference gathered in order to address the issues appearing after the World War I and to settle such issues from the standpoint of the victorious countries, in which delegates, advisors, and delegates from Europe to the Middle East, from Caucasus to South America, started on $18^{\text {th }}$ January 1918, it bore several features which would allow the order appearing after the 1815 Vienna Congress to be addressed in the broadest sense. Or, to say

\footnotetext{
${ }^{6}$ Helmreich, 1996, p. 4.

${ }^{7}$ Helmreich, 1996, p. 5.
} 
the least, all victorious/defeated states attributed great importance to it in this way and had hopes therefrom.

While the diplomats of the victorious states that constituted the "Council of Ten" immediately started their work for the peace treaties to be signed with the defeated countries at the conference, the delegates of such elements as Greeks, Armenians, Kurds and Arabs, who claimed rights on the territories breaking off or planned to break off from the Ottoman State had also come to Paris in order to tell their accounts to the great states.

\section{Emir Faisal's Endeavours in Europe}

Undoubtedly, among the most disputed issues at the Peace Conference, the status of the Arabs was the leading one in association with the re-shaping of the Middle East. Although the Allied council had listened to the claims of several ethnic groups about the territories which would be broken off from the Turks, the status of the Arabs would be required to address with a great difference and privilege as compared to the other ones. The action had been taken together with the Arabs in the removal of the Ottoman sovereignty in the Middle East and the British and French authorities provided them with unlimited support of arms and money as if they fairly wanted to display their commitment to their promises in innumerable meetings. While, conscious of all these facts, Sharif Hussein was preparing to send his son Faisal as the head of the Arab Delegation to Paris, the British and Frenchmen kept talking to make modifications in the Sykes-Picot Agreement in London before the conference started. As it has been stated earlier, as Great Britain started to get disturbed by the existence of this agreement, they tried to convince the Frenchmen for such a modification by making reasonable proposals to them. Clemenceau and Lloyd George gathered for such modification and the first modification was talked over in London on $1^{\text {st }}$ December 1918. When Lloyd George expressly told Clemenceau in the meeting that he wanted Mosul and Palestine, the French Prime Minister had to helplessly agree to this proposal as he needed Britain's support in order to stop Germany in Europe ${ }^{8}$. Thus, even before the beginning of the peace conference, although Great Britain had overcome obstacles in order to settle down in Mosul and Palestine, they also allowed the French forces to settle in Syria and Lebanon despite severe reaction from the Arabs. Unaware of all these developments, Faisal prepared to set out for a European tour of which

\footnotetext{
${ }^{8}$ İskit, 2017, p. 213. According to the report issued by the Admiralty, what suddenly warned Great Britain on the fact that Mosul had to be kept Mosul in hand at all costs was the existence of gigantic oil reserves in Mosul. As a matter of fact, this fact was mentioned in the reports issued on Mosul by Germans. Barr, 2016, pp. 74.
} 
he cherishes great hope in order to both attend the Paris Peace Conference and find some support to his cause throughout Europe.

Accompanied by a staff of advisors that he hoped to serve the great Arab cause, Faisal started from Beirut and arrived in the Port of Marseilles on $25^{\text {th }}$ November 1919. While he was still on the road, Lawrence, who would serve as his major advisor and interpreter and help him make his appearance in the European arena, in any case, started from London to Paris in order to join him. When Faisal set foot in the French territories, he was simply and extremely inhospitably met by Emmanuel Bertrand, an official of the Foreign Ministry who was completely authorized by the French Government and specially instructed on how to treat him. This would expressly constitute the French Government's attitude towards Faisal during the conference. Because Faisal and the Arab cause started to pose an adverse situation for the French ambitions and interests in the shaping of the Middle East in the post-war period. When the same attitude was maintained towards him when he arrived in Paris, Faisal could not stand it any longer and would react by saying, "We have fought the war together; we are brothers in arms. I trust your statements of friendship and loyalty. Tell me the case clearly. I have left behind my brother Zaid as my delegates in Damascus. He is young and inexperienced. I am concerned about the difficult situation in the country. If I will spend my time here in vain, I would better go back to Damascus," to Belford, who was appointed as an attendant for him $^{9}$. As a matter of fact, Faisal wanted to talk with Clemenceau and pass on to London as soon as possible before the peace conference. He thought that he was stalled off in France. Eventually, upon this reaction of his, Faisal would talk with the most authorized individuals of the French Government and then allowed to talk with Clemenceau and find an opportunity to learn the French Government's opinion on Syria and the Arab cause and give his own opinion thereon.

Faisal seemed to have understood more or less the intentions of the Frenchmen on Syria during two weeks he spent in Paris. Referring to this matter in a letter he wrote to his father on $12^{\text {th }}$ December, he stated, “...France wanted to grasp the control over Syria completely in the situation revealed upon the

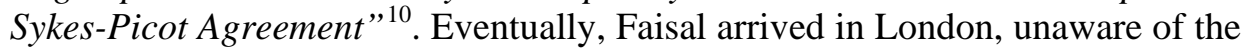
fact that important talks which would strikingly affect the future of the Arab territories occupied by the Allies were being held. The British received Faisal in an environment consisted of obligations, promises, and intrigues. Faisal, who was allowed to meet with the Foreign Secretary Lord Balfour on $12^{\text {th }}$ December,

\footnotetext{
${ }^{9}$ Allawi, 2016, p. 219.

${ }^{10}$ Musa, 1973, p. 251.
} 
wanted -in an extremely nervous manner- the British to keep the promises made to them in an environment where Lawrence was an interpreter. Having raised his voice against Balfour now and then during the meeting, Faisal vocalized that he had suspicions about Britain's being a friend of the Arabs and wanted it to be known that they did not agree to any arrangements in an environment where the rights of the Arabs were obliterated by the Sykes-Picot Agreement and the arrangements made and that they would inform the world of the malevolent schemes of the British and that they would fight anyone who would want to occupy their territories if they could not get help in resist the Frenchmen ${ }^{11}$. Having taken the floor in that stressful environment, Balfour said that the rights of the Arab nation would be fairly observed in the conference, thus trying to remove Faisal's worries, but the latter well noticed that clandestine plots were being made behind them in London. In fact, Faisal's concerned and doubtful attitude after the meeting prominently showed up in the meeting with both the British King and in the meeting with Lloyd George, who made great efforts in order to appease him $^{12}$. In fact, in all that tumult, the British government carried out extensive intelligence activities as to what was Faisal's nature and what kind of reconciliation would be established between him and the Frenchmen at the minimum level. In a report on Faisal sent from Cairo, it was stated that he wanted to establish an Arab Federative State under a single flag, which has money circulation and customs, and that he would not make any sacrifice of it. It was further underlined that he would not by any means allow the Frenchmen to intervene to prevent it ${ }^{13}$.

Having talked with Dr. Weizmann, leader of the Zionist cause, in the period when he stayed in London, Faisal wanted support from the Israelis for their cause and said that the Palestinian territories were open to the Jews, whom he considered brothers of the same race, provided that the latter would recognise the Arab Government and freedom ${ }^{14}$.

${ }^{11}$ Allawi, 2016, pp. 223-225; When the Bolshevik revolution occurred and the Soviets grasped the government in Russia in the last year of the World War I, they announced to the world public opinion the partition agreements which the Allies had made between themselves in the first place. The Ottoman Government that became aware of the existence of the Sykes-Picot Agreement immediately notified Sharif Hussein of such a secret agreement via Fahrettin Pasha, who was in Medina. However, Sharif Hussein considered such news to be a Turkish propaganda and did not believe in the existence of the agreement. Koloğlu, 1994, p. 94.

${ }^{12}$ Koloğlu, 1994, p. 226

${ }^{13}$ FO. 608/92, No: 12033, “Report on Emir Faisal’s objectives”, 30 $0^{\text {th }}$ January 1919.

${ }^{14}$ Faisal met with Dr. Weizmann several times during his stay in London. In such meetings, Faisal wanted support from the Israelis through lobbying activities for the Arab cause while Dr. Weizmann was trying to have Faisal sign an agreement containing some obligations. In fact, Weizmann had Faisal sign an English text for the recognition of the Zionist claims through the 
Having maintained his rounds for support before the peace conference, Faisal left the meeting which he had last held with Lord Curzon quite hopeful. In the meeting held quite sincerely at Curzon's house, Lord Curzon wanted Faisal to prepare a memorandum containing Arab claims to be presented to the peace conference. Further, Faisal would tell Curzon in the meeting that he did not want to allow anything but a symbolic existence for the Frenchmen in Syria and state that he would do it just for his commitment to Great Britain and for the sake of Great Britain ${ }^{15}$.

Before the peace conference, Faisal started to look quite hopeful of the talks in London as compared to those held by the French authorities in Paris. The fact that Faisal heard such an open support to their historic cause from Great Britain, which he called "Our Greatest Ally" gave him morale and courage ${ }^{16}$.

Emir Faisal presented the memorandum about the Arab claims to the peace conference in a half enemy and half skeptical environment within the opportunities allowed to him on $1^{\text {st }}$ January 1919. In the memorandum, Faisal required freedom to be given for all the territories remaining in the south of the Alexandretta line. As a reason for this, Faisal set forth the natural borders constituting the social and economic unit of the region and argued that more than $99 \%$ of the people came from the Semitic race and believed in the same religion in the regions for which freedom was claimed.

Even if he agreed that it was not quite possible due to some economic and social differences, Faisal personally emphasized that he was for an Arab union under the mandate of a single state. Despite he wanted to see Lebanon free, he was aware that some Lebanese would want French protection. He only wanted a bond which would constitute an obstacle for Lebanon's attachment to the Arab Confederation in the future not to be so strong.

Faisal vocalized that he wanted Syria to have an independent status away from external control and underlined that it would yet be a proper decision to send an international delegation to Syria in order to fully understand the wish of the Syrian people. He pointed out that a separate state should be established under political guidance for Mesopotamia and that an independent state should be established through the organization of tribes for Hejaz. He vocalized that he would agree to the mandate of a European power in the region in such a manner which shall take the Zionist interests into account in Palestine ${ }^{17}$. Faisal based

inculcations by Lawrence and pressure by the British after many attempts. However, while signing the text, Faisal annotated a sentence such as "I agree to the foregoing provisions on condition that the Arabs shall win their freedom”. Antonius, 1989, s. 439.

${ }^{15}$ For information on Faisal's talks in London, see. Öke, 2011, p.311-330; Allawi, 2016, pp.223-237.

${ }^{16}$ Antonius, 1989, p. 439.

${ }^{17}$ Helmreich, 1996, p. 39. 
these claims of his on the US President Wilson's Mount Vernon speech of $4^{\text {th }}$ July 1918 and on the principle of people's self-determination as contained in the latter's points released in January 1918. These claims vocalized in the memorandum were formally communicated to the Council of Ten on $6^{\text {th }}$ February. As a matter of fact, the Council of Ten had decided to break the territories where the Armenians lived off from Turkey along with the Arab territories 7 days prior to Faisal's giving his speech before the council ${ }^{18}$.

Immediately after the memorandum, Faisal tried to create an affirmative atmosphere about the Arab cause by making a statement to the press in Paris. Appearing before the Council of Ten under the reactive looks from the Frenchmen as a result of profound efforts by the British, Faisal found an opportunity to communicate his cause to the Allied council members via the essentials he had earlier mentioned in the memorandum in a quite fluent and attractive tone on $6^{\text {th }}$ February ${ }^{19}$.He was directed questions by both Lloyd George and President Wilson after his speech and replied such questions addressed to him in great self-possession. Faisal's impressive speech before the council rather disturbed the French authorities. As a matter of fact, they also tried to have someone called Shukru Ganem, who was originally an Arab but had been living in France for many years, address to the council and make statements contrary to Faisal's views ${ }^{20}$. As expected, this move disturbed Faisal to such extent that he would immediately write a letter to his brother Zaid, who was in Damascus and want the leading ones of the notables of Syria to send telegrams to the peace conference and notify that they elected him the delegates of the Syrian people ${ }^{21}$.

After he addressed the council, Faisal kept staying in Paris for a while in order to see in what way political developments would affect his own cause ${ }^{22}$. During the days when Faisal kept staying in Paris, an important development which is closely concerned with Syria and the Arab cause. A meeting was held between Lloyd George, Clemenceau and Wilson in Lloyd George's office in Paris on $20^{\text {th }}$ March. Even if the British-French tension on Syria would mark the

\footnotetext{
${ }^{18}$ Yavuz, 2016, p. 303.

${ }^{19}$ Macmillan, 2004, p. 383

${ }^{20}$ Evans, 2003, p. 129; Shukru Ganem, Chairman of the Syrian Central Committee was prepared by the French intelligence to address to the council in order to confute Faisal's claims. Haydar, 1988, p. 233.

${ }^{21}$ FO. 608/92, No: 6816, $5^{\text {th }}$ March 1919.

${ }^{22}$ Lansing, 1922, p. 162; During this time, Faisal made statements to several newspapers in order to convince the European public opinion about the Arab cause and win their support. He was especially alert against any publications which would jeopardize the rights of the Arabs at all times. FO. 608/92, No: 1694, $7^{\text {th }}$ February 1919.
} 
meeting, a decision was made in the meeting which proceeded in the form of a mutual discussion as to send an international commission to learn the tendencies of the local people in the Middle East and Near East. In order to make a contribution to the signing of the Turkish peace and to bring peace to the Middle East, the commission was required to be established by the request of President Wilson himself ${ }^{23}$. The commission which the British and Frenchmen initially agreed to give members would be subsequently consisted only of Americans for various reasons and set out for the Anatolia and Near East visit in the summer months of $1919^{24}$.

The decision to send an international commission to Syria and the Middle East was a development which would considerably strengthen Faisal's hand. In fact, Faisal did not lose more time and immediately returned to Damascus in order to speed up the works for welcoming the commission. He convened the Syrian General Congress and focused on welcoming an international commission entirely consisted of Americans, which went by the name of KingCrane, a very short while after his return to Damascus ${ }^{25}$. For this purpose, Faisal sent word to Yasin Pasha, Commander General of the Arab Armies in Syria, and instructed him to cause the local people to act in accordance with the propaganda works and look like a single nation before the commission. Instructions were sent to all religious order and tribe leaders in Syria ${ }^{26}$.

In the statement which the international commission made upon their return to Paris once they had completed their works under the endeavours of the Arabs and Frenchmen trying to overwhelm each other, they stated that, except for Anatolia, a great majority of the local people was against the separation of Syria and Palestine and the region's becoming a Zionist Jewish territory. In their statement, the commission further told that other than the Christian population concentrating in Lebanon, the local people usually preferred United

${ }^{23}$ Öke, 2011, p. 318.

${ }^{24}$ FO. 608/92, No: 5700, 29 ${ }^{\text {th }}$ March 1919; Even if Lloyd George, Clemenceau and Orlando initially supported the establishment of such a committee, they afterwards gave up giving members to the committee to be established lest "an investigation committee would further disturb the settlements in the east as it would stir up unforeseeable hopes and create agitation...”. Bilgen, 2004, pp. 68-70; Frenchmen started to treat the committee as an indecent plot intended for forfeiting the rights recognized by them under the Sykes-Picot Agreement. The British avoided giving members to the committee due to the pressure from the Frenchmen. Besides, the Zionist organizations were against the establishment of such a committee from the beginning. Allawi, 2016, p. 299.

${ }^{25}$ Barr, 2016, p. 94; Faisal would further take action to communicate the decisions made by the Syrian General Congress to the peace conference via Rustem Haydar Bey, who was in Paris, as soon as possible. FO. 608/92, No: 12032, "from General Clayton to Lord Balfour", $4^{\text {th }}$ June 1919.

${ }^{26}$ FO. 608/92, No: 13156, $5^{\text {th }}$ June 1919. 
States mandate or, as a secondary option, that of the British ${ }^{27}$. The same majority also insistently told that they did not want any sort of French mandate, notwithstanding how small it was ${ }^{28}$. Having included the activities of the British and French propaganda organizations operating in the region in their report, the commission accused the Frenchmen of writing influencing articles in newspapers and preventing the commission from learning the actual views of the local people through espionage activities and by creating fear among the local people. However, the report stated that despite such preventive attempts of the Frenchmen, almost sixty percent of the petitions sent to the commission by the local people contained opposition to the Frenchmen ${ }^{29}$. Despite the report of the commission was prepared just as the Arabs wanted, the Frenchmen and the British did not make the report public although it was presented to the Council of Ten in Paris. Undoubtedly, it was underlined by the fact that the United States focused on their domestic politics and did not want to play a decisive role in the Middle East issue, thereby in the determination of the terms of the Turkish peace treaty ${ }^{30}$.

Despite the works of the King-Crane Commission and the works of the Arab Delegation in Paris and London, Lloyd George and Clemenceau put the essential modifications in the Sykes-Picot Agreement under an agreement which they signed on $13^{\text {th }}$ September 1919 as they had agreed in December 1918. According to the agreement which would become effective on $1^{\text {st }}$ November 1919, French units would be deployed on the Cilician and Syrian coastline instead of the British forces and Faisal's governmental forces in the cities of Damascus, Hama, Humus and Aleppo ${ }^{31}$. And the British usually settled in the Iraqi geography. While Faisal, unaware of this agreement reached between the two allies, was proceeding with his lobbying activities with Arab notables in Damascus in order not to allow the Frenchmen in the Syrian territories, Lloyd George invited Faisal to London in order to tell him of the agreement so reached in a proper language ${ }^{32}$. When Faisal arrived at the port of

${ }^{27}$ Barr, 2016, p. 94.

${ }^{28}$ Helmreich, 1996, p. 103.

${ }^{29}$ Barr, 2016, p. 94.

${ }^{30}$ Commission report was presented to the US Delegation staying in Paris in August 1919. Nevertheless, the report was kept under the mat for three years. It was not published by December 1922 which is the date when mandates system was established and actual partition of the Middle East was registered. Öke, 2011, p. 321; For further detailed information on the King-Crane Commission, see. Karakaya, 2001.

${ }^{31}$ Allawi, 2016, p. 303.

${ }^{32}$ In fact, the British Government was in a rather distressed condition as to how to convince Faisal. The British Foreign Ministry further assigned their embassy in Paris for reaching conciliation between Faisal and the French Government. FO. 608/92, No: 7864, $22^{\text {nd }}$ April 1919. 


\section{Effects of The Decisions of San Remo Conference on Syria and Iraq}

Marseilles to go to Europe, he understood that something was going on by the attitude of the Frenchmen and expressly vocalized this fact in a letter he wrote to his brother Zaid. In such disappointment and dispiritedness, Faisal would be entertained in London by Lloyd George and other British delegates. In the talks held here, Lloyd George would try to tell Faisal that Great Britain should withdraw from the region but this, as expected, would not satisfy Faisal $^{33}$.Consequently, Faisal would be sent to Paris to reach an agreement on Syria with France in proper terms once he had been hopelessly notified of the agreement in great disappointment.

Even if Faisal tried to turn France away from making such a move in the talks he held with Clemenceau in Paris, the Frenchmen had already deployed their soldiers to the region and Cilicia ${ }^{34}$. The Frenchmen had even appointed General Gouraud as the commander of the soldiers that they had deployed in the region including Cilicia as per the agreement reached with the British ${ }^{35}$. When he could not get any results from his attempts of conviction which lasted many days in London and Paris, Faisal immediately passed on to Damascus in January 1920. In the meanwhile, the French units had started to increase their military existence in Syria, especially in the Beqaa Valley. While the French forces made efforts to take a position in Syria in this way, on one hand, they also engaged in severe combat with the Turkish forces at Cilicia, especially in the Urfa and Maras regions on the other. Following all these developments closely, Faisal opened the Syria Congress on $6^{\text {th }}$ March $^{36}$. After vehement speeches given on the first day of the congress, on $7^{\text {th }}$ March, the congress made a decision as to the fact that Syria has an independent and constitutional monarchical government within its natural boundaries including Palestine -in an economic unity with Iraq. And one day later, Faisal was crowned as the first king of the United Syria covering Lebanon and Palestine in the Town Hall of Damascus ${ }^{37}$.Moreover, Faisal wanted the Frenchmen and British to leave the west (Lebanon) and south (Palestine) of Syria. In the meanwhile, while these were the developments in Syria, a General Congress was also gathered in Iraq in line with the incidents and it was announced that Iraq was a fully independent state under Abdullah, Faisal's elder brother, as the king.

\footnotetext{
${ }^{33}$ Evans, 2003, p. 225.

${ }^{34}$ Sharif Hussein, who was much concerned about Faisal's meeting with Clemenceau in Paris notified his son that he should only negotiate with the British on Syria and that this is the basic rationale of their policy and that he gave that order to his son "as his father and chief" in a letter he wrote to his son from Mecca. FO. 608/92, No: 14426, $24^{\text {th }}$ June 1919.

${ }^{35}$ Grainger, 2015, p. 280

${ }^{36}$ Grainger, 2015, p. 282.

${ }^{37}$ İskit, 2017, p. 232; Umar, 2004, p. 414.
} 
As it may be guessed, the British and French response to such developments very rapidly experienced in Syria and Iraq was rather harsh as from the very first moment. Britain's new Foreign Secretary Lord Curzon sent an instruction to General Allenby on $13^{\text {th }}$ March and wanted him to tell Emir Faisal that the Damascus Congress on which they did not have any information was not entitled to determine the future of Syria, Palestine, Mosul or Iraq and that both the British and the French governments ignored such decisions.

\section{Decisions of the San Remo Conference about Syria and Iraq.}

As a matter of fact, the Allies had profoundly worked from January to April in order to give the Turkish peace which had turned into a long-winded story its final form in the absence of the Americans in London. As the Allies failed to settle several issues between them in the talks held here, they could not give the Turkish peace its final form on which they would all agree. Moreover, the Turkish National Struggle of Independence occurring under the leadership of Mustafa Kemal in Anatolia came into being and such struggle found an astute base by choosing Ankara as headquarters upon the occupation of Istanbul by the Allies. Undoubtedly, when this is considered together with the fait accompli occurring in Syria and Iraq under the shadow of the latest developments, it would cause the Allies to start the final meetings to be held in San Remo in so stressful a manner. Furthermore, when the situation in the Near East and the Middle East had become so complicated, the fact that the US Government started to strike an attitude remotely despite all calls from the Allies in an environment in which the last turn had been taken in the determination of the Turkish peace rather disturbed the British and French authorities.

In the conference which would take approximately one week, the Allies would put on the agenda of the conference such issues as Turkey's Thracian border, territories to be granted to Armenians out of the Turkish territories, status of Kurds, future of the Arab territories in the Middle East as well as such issues as oil concessions in Mesopotamia. The conference held numerous sessions in the morning and in the afternoon until $28^{\text {th }}$ April when it accomplished its meetings. In those sessions, harsh debates would take place between the Italians and the British, with the participation of the Frenchmen from time to time, on the locations to be granted to the Greeks in Anatolia. Further, what sort of a rule Syria, Mesopotamia and other Arab regions, which would be detached from the Ottoman State, would be given and what rights would be granted to the local Arabic elements during such rule as it had been promised earlier would cause some tension to be experienced between France and Great Britain. 
In the San Remo talks, the Allied Commission put the Kurdish issue which closely concerned the region including the Iraqi geography on the agenda of the conference upon Lloyd George's request. As a matter of fact, this issue had been made the Allies busy -even if not too intensively- at a pace which increased now and then since it was put on the agenda of the Paris Peace Conference convened in January 1919.

In the conference session dated $19^{\text {th }}$ April, Lord Curzon gave a long speech on the Kurdistan issue and vocalized that it was a difficult issue to make any decision on the matter. Curzon stated that he had sought for a collocutor concerning the Kurds in Istanbul and Baghdad but that he could not find anyone who would properly represent the Kurds and repeated that the Kurds acted with a tribal spirit and were not of such maturity as being capable of standing alone by themselves as a state and said that he was of opinion that the Kurds should be under the protection of the Turks ${ }^{38}$.The Frenchmen thought in line with Lord Curzon in the meeting. As a matter of fact, these two states rather looked to the issue from the standpoint of their interests in Mesopotamia and attempted to guarantee their share in the Mosul oil. However, even though Great Britain and France yet felt it necessary to reach conciliation on imperial interest in the Kurdish region, they favoured the inclusion of a clause about granting autonomy to Kurds in the peace draft ${ }^{39}$. Nevertheless, while it was decided that the Kurds living in the Mosul region would be ruled by the British, it was also agreed that the Kurds in this region would be free to remain under the British rule or merge with Kurdistan if an independent Kurdistan would be established in the future. A commission consisted of British, French and Italian delegates would prepare an autonomy plan and project for Kurdistan. It would be stipulated that the Turkish Government would agree to the commission decision in advance with provisions to be included in the treaty and independence claim of the Kurds would be referred to the League of Nations once the treaty had become effective. If the League of Nations would eventually consider such decision valid, the Turkish Government would agree in advance to lose all their rights on Kurdistan ${ }^{40}$.

When one looks into the negotiations in the conference, the British and Frenchmen seemed to have settled the issue in their own way. However, when one looks into the reports coming from the civilian and military representatives in charge on site, the issue was in so complicated a state that the fact that the probability of bringing peace to this region calmly was even too difficult was

\footnotetext{
${ }^{38}$ Olcay, 1981, p. 466.

${ }^{39}$ Lazarev 1989, p. 155.

${ }^{40}$ Baytok, 2007, p. 124.
} 
almost accepted when it was considered together with the Armenian issue ${ }^{41}$. Because despite the Armenian issue had been assigned to the US Government, the indecisive attitude of the US Government in undertaking this issue and settlement of the Kurdish issue with artificial borders seemed that permanent peace would not be achieved in the region in the long run.

Therefore, when one looks into the decisions made about Kurds in San Remo, it would be revealed that the Allied states endeavoured to achieve their own goals by dividing the Kurdish region into their own economic and political spheres of influence rather than establishing an integrated Kurdistan as it had been claimed since early 1919; and this fact revealed their perspective on this issue $^{42}$.

By the way in the sessions of the San Remo Conference held on $24^{\text {th }}$ and $25^{\text {th }}$ April, the issue of future of the Arab territories broken off from the Ottoman State was discussed. It had already been addressed in the talks which had taken many months in London and Paris. When the Palestine issue was first addressed in the present negotiations, both Lord Curzon and his French counterpart agreed on the fact that an arrangement had to be done so that Palestine would not be ruled by the Turks any longer. However, as Palestine was considered sacred by the denominations of all three major religions, the commission members pointed out that it would be useful if the decision on the arrangement to be made for sacred places would be made by a committee to be established under the League of Nations. As a matter of fact, while this proposal was also accepted with great pleasure by Lloyd George, the fact that vocalisation of religious and denominational concerns rather than governmental ones was something which relieved Great Britain in the negotiations, because the British Government could not definitely withstand their being hindered in mandating Palestine ${ }^{43}$.

In the sessions of the Conference held on $25^{\text {th }}$ April, the status of Syria, Lebanon, and Iraq was put on the agenda. As a matter of fact, the future of these regions had been decided upon in the secret and explicit negotiations held between the two allies earlier. This decision was to approve it without any disputes in the negotiations at San Remo. Accordingly, it was formally decided that French mandate was to be created in Syria and Lebanon within the scope of the League of Nations and that Mesopotamia, including Palestine, was to be put under the mandate rule of Great Britain. It was further agreed that the borderline between the French and British Mandate regions would be confirmed as it had

\footnotetext{
${ }^{41}$ Lazarev 1989, p. 157.

${ }^{42}$ Lazarev 1989, p. 158.

${ }^{43}$ DBFB 1919-1939- First Series, Volume 8, P. 95-104, No: 9.
} 
been earlier decided between these two states so that no problem basing on border disputes should ever arise between Great Britain and France in the future $^{44}$.While the status of Syria and Lebanon was discussed, Lord Curzon, in somewhat apprehensive manner, referred to Faisal's position and advised that he would be notified of the situation as well ${ }^{45}$. Because all who had an authorized status knew the fact that the decisions made at San Remo would not please the Arabs, including Faisal, awaiting the decisions to be made in the conference. Since Great Britain was kind of urged to make a choice between Faisal and France on the Syria issue, they were very much concerned about the fact that Faisal's position would not remain limited to Syria and furthermore that the issue would pass on to Palestine and Iraq as well in case of some dissatisfaction while drawing closer to France.

While mandate rules issue was decided upon in this way, the distribution of oil resources issue was also addressed by the Allied States but no argument which would lead to significant differences of opinion or tensions was experienced on this matter as it was on the issue of mandates; because the British and French authorities have already decided how the oil concession regions in the Middle East would be divided and how the rights would be in the previous negotiations. In the San Remo negotiations held on $24^{\text {th }}$ April, the parties reached an agreement on the oil concessions which had been made final earlier ${ }^{46}$.Thus, the Allied Commission seemed to have settled the problem of how the future of the Arab territories broken off from the Ottoman State would be.

\section{Responses Rising from Syria and Iraq to the Decisions of the San Remo Conference}

Since the issues handled by the Allies in San Remo over a period of one week were actually the problems that had been discussed for months, both the Islamic world and the world community were closely following the final decisions to be made. But although this anxious expectation was rather between the Turks and the Arabs, Indian Muslims were also following the conference decisions at least as close as they were. Even, for this purpose, the members of

\footnotetext{
${ }^{44}$ FO. 371/ 5035, No: E 3810, "Cipher Telegram from Lord Curzon to the British Foreign Ministry”, 26 ${ }^{\text {th }}$ April 1920.

${ }^{45}$ Haydar, 1988, p. 624.

${ }^{46}$ According to the agreement reached, it was decided that France would hold 25\% of the shares of all the private oil companies in Mesopotamia. Furthermore, a new clause was added to this agreement at San Remo and the French Government was granted the right to purchase a portion of $25 \%$ of the oil produced in Iran and passing through the territories under the French mandate rule while being shipped to the Mediterranean. DBFB 1919-1939- First Series, Volume 8, P. 95-108, No: 10.
} 
the Indian Khilafatists Association made intensive efforts to prevent the division of the Ottoman lands by meeting with heads of state of the Allied countries in London and Paris before the conference was convened. As the San Remo Conference was ongoing, the members of the association responded to the Allies with the following statements: "You won the war thanks to us, but when it comes to peace, you do not take our concerns into account. Our people cannot accept a peace in San Remo, with a few people behind closed doors, which ignores their consciences, their beliefs and the things promised to them...”,47

Not only the Indian Muslims but in addition to those who were defeated in the battle, even Lawrence, who struggled with the Arabs to remove the Turks from the Arab lands, was in great shock because of the decisions of the San Remo Conference. Stating that the decisions were taken with great vengeance, Lawrence expressed that decisions could not bring the expected peace and that even one article could not last three years ${ }^{48}$. Arab associations in Europe were also protesting the decision about the split of Palestine from Syria ${ }^{49}$. However, the decisions were made and the Allies acted to implement the decisions without delay. Thus, immediately following the San Remo Decisions, the Allies called for the Ottoman Government to sign the peace treaty, while, on the other hand, they had sent instruction to General Allenby to tell the situation to Faisal as soon as possible because of Lord Curzon's concerns about the reaction of Arabs against the decisions ${ }^{50}$. On April 27, Allenby sends a telegram to Faisal to let him know that Syria had been given to the French mandate, and Iraq and Palestine had been given to the British Mandate. Allenby also stated in the telegram that the Allies recognized the independence of Syria and Iraq, and it was stipulated that they would be under the mandate of a great power until they stand on their own legs. Faisal, who is informed about the decision of San Remo, sends a note to Allenby with great disappointment and tells that Syria and Iraq are welcomed to be independent, but that the implementation of the mandate system in these states would be unacceptable. In addition, Faisal also told Allenby that Palestine, a natural part of Syria, would not be allowed to split from this country and a Zionist structure would not be allowed $^{51}$.

${ }^{47}$ Öke, 1999, p. 62.

${ }^{48}$ Koloğlu, 1994, p. 145.

${ }^{49}$ FO. 371/5035, No: E 4117, April 1920.

${ }^{50}$ FO. 371/5035, No: E 3965, “Encrypted Telegram from Cairo to General Allenby”, April 1920, Allenby wanted authority from London about whether or not Faisal's informing of the conference's decisions, according to the gravity of the situation, would be reported to Sharif Hussein. FO. 371/ 5035, No: E 4231, May 1920.

${ }^{51}$ Allenby conveyed Faisal's reactions to London with an urgent code without losing time. Faisal reported in his letter of protest he sent to London via Allenby that the Syrian people would not accept the mandate and that he and the Arab people refer to the establishment of a united Arab 
In fact, Faisal's reaction was an example of the reaction of the whole Arab world. The Hijaz Committee, representing the Arabs at the peace conference, also announced to the whole world with the following statement that they had severely protested the conference decisions: "The Arabs had joined the Allies in the war against the Turks to get rid of the oppression of foreigners and to enter the free nations' community. The Arabs who knew their rights and their duties did not hesitate to take up arms against their religious fellows. San Remo Decisions are destroying this hope. The moderate elements of the young nation trying to establish a sincere cooperation policy with the Allies remain ineffective in this case. ${ }^{, 52}$

Faisal, however, was not able to dispense with England, the country that could best understand them. In a letter he wrote to Lord Curzon on June 5, he informed that the French authorities in Beirut had deployed arms to the Christian people against Muslims in the west of the country, warning that this would cause serious disturbances in the country. Faisal also said to Curzon that it would never be accepted if the French intended to "divide and rule" in Syria. The reactions rising from official delegations turned into street actions in a very short time in a way to cause the people to overreact in Syria and Lebanon. With the ongoing strikes and demonstrations, the government had to resign in Syria. Then, the new government, which took office in May, began to carry out a series of actions, openly responding to the decisions of the Allies, including compulsory military service. Faisal wrote a note to General Gouraud, who was France's top military representative in Syria, in an environment where he began to worry about not being able to control the growing reactions against the Allies, particularly against the French. In the note, written in an extremely brave and demanding style, Faisal demanded that France recognizes Syria's sovereignty and withdraw its troops throughout Syria, except Lebanon, as stipulated in the peace conference. With this note, Faisal strived to pursue a general appeasement policy without causing further escalation of the events. But General Gourand's answer to this note would not be what Faisal expected at all, and the French general would indifferently reject Faisal's demands ${ }^{53}$.

As the show downs between Gouraud and Faisal continued with notes, uprisings against the San Remo Decisions began in many regions of Syria and Lebanon. The uprisings, which first took place in the French occupation

kingdom, including Palestine, agreed between Mc Mohan and Sharif Hussein in 1915. Faisal also expressed in the letter that the Palestinian people would not recognize any treaty or contract that would ensure Palestine to become a Jewish homeland. FO. 371/5035, No: E 4698, May 1920.

${ }^{52}$ Koloğlu, 1994, p. 84.

${ }^{53}$ Allawi, 2016, p. 345. 
territories, expanded further and spread to the Shiite regions in Lebanon. After the French troops vigorously suppressed them, another uprising began this time in the Idlib province of northern Aleppo. The French have tried to prevent the Christian leaders from contacting Faisal, worrying about the spread of the uprisings in the Christian regions as well. Then, within the frame of a series of precautions, General Gouraud put an end to the practice of reading sermons in the name of Faisal in the mosques of the region, forbidding the Arab flag hanging on the Syrian Liaison Office in Beirut. In response, Faisal's forces put a hold on the Aleppo-Rayak railway, which they had first allowed its limited use by the French, on May 21 with public oppression ${ }^{54}$.

The fact that the Arabs acted like this in Syria and Lebanon with the direction of Faisal forced the French government to harshly intervene the uprisings on the one hand while the on the other hand the inexorable struggle against the Turkish revolutionaries in Cilicia Region had forced the French government to the wall. Recognizing the difficulties in both front lines, the French government intended to launch a ceasefire with the Turks to put an end to the military occupation of Cilicia, which failed against the Kemalist forces.

In fact, in a telegram sent by the French Embassy in London to Paris, it was drawn attention to this to not to allow any plot to jeopardize France in the region $^{55}$. Thus, the French were struggling to cut off the possible contact between Mustafa Kemal and Faisal, based on the news from the intelligence sources. Despite the British were aware of the possible connection between Faisal and the Turkish Revolutionaries in Anatolia, the British government was beginning to worry about these moves of the French and was following in great surprise news about the evacuation procedures in Cilicia. But France did not want to get into a dilemma in Syria, just as it was against the Turkish forces in Cilicia. For this purpose, Millerand, the new president of France, would give General Gouraud full authority to bring the end of Faisal and to effectively implement the decisions of the San Remo Conference in Syria ${ }^{56}$.

During these developments in Syria, similar rebellion attempts against the British administration in Palestine and Iraq would begin to be seen.

Unresthad begun in Palestine before the San Remo Conference was convened. The occupation of Jerusalem in 1917 and the demonstrations of the Zionists on the first anniversary of the Balfour Declaration in the city (1918) had made the Palestinians rather uncomfortable. Following these developments, the mayor and the Palestinian notables met with the Occupation Forces

\footnotetext{
${ }^{54}$ Allawi, 2016, p. 347.

${ }^{55}$ FO. 371/5035, No: E- 5598, 9 May 1920.

${ }^{56}$ Umar, 2014, p. 444.
} 
Governor Storrs and presented their protest notes. Shortly after that, some people tried to transform the struggle with Zionism into an organized one by establishing the Muslim and Christian Association in the city. While continuing to work on the one hand, the association accelerated its efforts to "warn" and "awaken" the people against the Zionists through propaganda activities by opening branches in various places. These active organizations were influenced by the "Arab Awakening" under the leadership of Faisal in Syria. In January 1919, the said association organized a congress and adopted an Arab Federation program, which would be headquartered in Syria under Faisal's presidency. Even a long memorandum was written in the congress covering the demands to be sent to the Paris Peace Conference ${ }^{57}$. While such works in the city increased the tension, in 1919 the Bedouin tribes in Jerusalem set off an Arab-Jewish battle by beginning to attack the Jewish settlements under British and French military rule. As the attacks increased in the early 1920s and spread to other regions, the English began to worry about the situation ${ }^{58}$. Thus, on April 4, the celebrations of Arabs on the declaration of Faisal's kingdom on the Muslims' Nabi Moses' Day in Jerusalem were soon converted into reactions against Jews. Five Jews, four Arabs were killed and two hundred and fifty persons, most of them Jews, were injured in four days of fighting. Although the Jews accused Storrs, who had been newly appointed as the Governor of Jerusalem by the British Administration, for events to develop in this way, the events emerged in Palestine would go on incessantly and especially the events after San Remo would turn into large events of response. So much so that upon the April 4 events, the English went with extensive investigative powers and intended to carry out the inquiry in a fair manner to show their presence to Jews and Arabs in Jerusalem. However, despite all these precautions, the English could not prevent the tension. On June 13, 1920, even pro-Zionist Winston Churchill was impressed by the march of events and would say in his letter to Lloyd George, "Occupying Palestine costs us six million a year. The Zionist movement will cause conflict with the Arabs. The French are against the Zionist movement and they will try to convince the Arabs that we are the real enemy. The Palestinian adventure ... will bring no tangible benefit. "59

\footnotetext{
${ }^{57}$ Öke, 2011, p. 332-333.

${ }^{58}$ Fromkin, 2004, p. 370.

59 After General Allenby invaded Jerusalem, there were British soldiers and civilian managers who thought that the implementation of the Balfour Declaration in Palestine would spell troubles here, and thus did not favor the establishment of the Jewish State. These managers did not hesitate to criticize the Zionism policy that London regarded as "creating trouble". Fromkin, 2017, p. 371.
} 
Therefore, many events that took place in 1920, especially the developments in Syria, would change the future expectations and perspectives of the Palestinians as a whole. The collapse of the Great Syrian Project by the France occupation caused the Palestinian Arabs to look for their independence in narrower and local patterns.

At the Palestinian Conference in Haifa on December 13, 1920, it was emphasized that the administration in Palestine was illegitimate and an arrangement would be demanded that would include the representation of the people in the League of Nations. Protest marches were held in many places in order to menace the British occupation immediately after the conference. Hence, the increasing confusion in Palestine after the 1920 San Remo Conference would have caused Churchill to take a Middle East tour, including Jerusalem, at the beginning of 1921. When Churchill arrived in Jerusalem within these visits in May 1921, the Palestinians had a series of demands including the rejection the Balfour Declaration and that the establishment of a Jewish state would not be accepted; but Churchill rejected these demands. In conclusion, even this extensive visit by Churchill, the Minister of Colonies, would not reduce the tension escalating in Palestine every day, but even in the ensuing years, particularly with the inurement of the Palestinian Mandate under the British administration in July 1922, the British Occupation Administration, on a knife-edge, would have to prevent the events in Palestine ${ }^{60}$.

While these developments were taking place in Palestine, similar incidences were experienced in Iraq, another occupation zone of Britain in the Middle East. In fact, the confusion in Iraq, especially in the regions where the Kurds and Arabs lived, had been ongoing since the invasion of the British forces in Iraq during the war. When the British seized the region, they set up a civilian administration that would keep the occupation area under control by not changing the Ottoman property system, which had been practiced for many years. Under the command of the civilian commissar, there were officers who could be called "Political Agent" who helped him particularly in financial and judicial matters but also on many subjects ${ }^{61}$.

In Iraq, the occupation management, which soon turned into pressure, began to disturb particularly the Arabs but also the Kurds and other Mesopotamian residents. Those who appealed to the British occupation had

\footnotetext{
60 Öke, 2011, p. 334.

${ }^{61}$ Gürün, 1986, p. 395. Towards the end of the war, Arnold Wilson was appointed as the head of the civilian administration in Iraq and Gertrude Bell was appointed as his assistant. These two were responsible for the administration of Iraq, particularly during the escalation of the events. Fromkin, 2004, p. 372; For more information about British administration in Iraq during the years of war, see. Satan, 2016.
} 


\section{Effects of The Decisions of San Remo Conference on Syria and Iraq}

begun to get rather disappointed towards the end of the war. Hence, the increasing unease towards the British administration first in Mosul continued throughout 1919, particularly during the months of the peace conference in Paris; but it reached its peak after the San Remo Conference ${ }^{62}$. Moreover, at the Syrian Congress in March 1920, the fact that Sharif Hussein had declared his sons Faisal and Abdullah as the kings of Syria and Iraq had put the British occupation on its guard. Because there was no sign that an Arab government would be established in Baghdad and Gertrude Bell was warning that such an initiative could cause trouble in Iraq ${ }^{63}$.

In June 1920, after San Remo Conference, the uprisings in Iraq were closely linked to the events in Syria. But these uprisings drew their strength from the fury against the three-year British Occupation Administration in the region ${ }^{64}$. In the morning of June 4th, a British garrison in Talafar was attacked by Faisal's military units.

Despite the immediate British reinforcements in the region, the continuance of the riot could not be quelled in a short period of time because of the underestimation of the insurgency. However, even though the British quelled the insurgency by suppressing the city with a devastating attack, the London administration had to ask Wilson's resignation and appoint Sir Percy Cox in his position by the mid-June. In addition, although the British Civil Administration in Baghdad gave approval to the law regarding the appointment of an Arab president to Iraq and establishment of a government assembly comprising of the Arab immediately after this appointment ${ }^{65}$, in July, it could not prevent a new uprising in Rumaythah, which was not far from Baghdad. The revolt, led by the nationalists and supported by the Shi'ite religious leaders, quickly influenced the tribes settled throughout the Euphrates lowlands. When the expanding revolt turned into a chaos and cut off the railway connections to the region, the supply lines of the British began to be seriously affected. Although the British Government tried to hide the magnitude of the uprising at first step, Churchill, bowing to the pressures, informed the British Parliament on July $16^{\text {th }}$, and the dimensions of the rebellion were learned by the opposition in London, which criticized the government's politics in Mesopotamia. The fact that Churchill tried to blame Faisal for the rebellions in the region in the information he gave to the parliament meant the desperate acceptance that the

\footnotetext{
62 Öke, 1992, p. 79.

${ }^{63}$ Barr, 2016, p. 118; Gertrude Bell, in her work she wrote about the events in Iraq in that period and the precautions tried to be taken by the British Civilian Administration, she stated that events in Iraq were ready to occur one after another. Bell, 2004, pp. 263-264

${ }^{64}$ Barr, 2016, p. 114.

${ }^{65}$ Öke, 1992, p. 81.
} 
events in Syria had begun to spread in Iraq ${ }^{66}$. In fact, the British government was caught unprepared for events that began to get out of control in Iraq. And this caused the influence of the British presence in the region to be questioned by a domino effect. Moreover, this led some politicians in the British Parliament, particularly Churchill, to see the truth and some politicians to tell that it at a time for British Government to withdraw the troops in Mesopotamia considering also the financial conditions ${ }^{67}$.

In the meanwhile, as rebellions continued in this way, a commission took office to determine the basics of the mandate administration in Iraq, as decided at the San Remo Conference. Although Lord Curzon directed the works of the commission to be built on local institutions in Iraq and encourage the establishment of an independent Arab state, some people in the Parliament wanted this to be postponed on the grounds that the time was not appropriate. Because the rebellion did not stop almost everywhere in Iraq and almost every day had started with a new problem in the shadow of the events in Syria ${ }^{68}$. Hence, in Iraq, a major attack on British bases was organized in Hilla in such an environment where things were getting even worse. The British forces suffered heavy casualties during the attacks in Hilla, the same day as the Battle of Maysalun between the French forces and Faisal in Syria, which caused Faisal to be expelled from Damascus in the wake of the French victory ${ }^{69}$.

After all, with the French forces to enter Damascus by using force at a time when the attacks of the Kurds and Arabs against the British Government increased in Iraq, the thought that the increasing violence in the Middle East would completely mess up Iraq had begun to spread both in the press and political circles. So much so that while the press criticized the government's policy in Mesopotamia in the most severe way, the thought that Faisal, who was expelled from Damascus, to be brought to Iraq and made the king would prevent the violence in the country had begun to prevail in some circles. When the newspapers on August 5 began to say that Faisal would be "the possible ruler of Mesopotamia ...", even the government circles in London had already begun to lean towards this idea ${ }^{70}$.

However, although there was a strong tendency in the ruling circles in London for that the problems in Mesopotamia would end with the accession of Faisal, there was in fact an idea that the problems there were provoked from the

\footnotetext{
${ }^{66}$ Barr, 2016, p. 119.

${ }^{67}$ Öke, 1992, p. 81.

${ }^{68}$ Öke, 1992, p. 81.

${ }^{69}$ Barr, 2016, p. 121.

${ }^{70}$ Barr, 2016, p. 121
} 
outside and the events that took place in the east in this regard were related to each other. All the intelligence reports had already suggested that the source of the events was Mustafa Kemal, the leader of the National Struggle in Anatolia, Bolsheviks in the Caucasus, Enver Pasha, Panislamists, German agents, and Faisal in Syria ${ }^{71}$. As is known, the events that took place in Iraq and Syria during that period were already closely followed in Anatolia. ${ }^{72}$

\section{Maysalun War and Faisal's Exile from Damascus}

The French forces immediately took action and began to intimidate Faisal as Millerand, the new president of France, granted General Gouraud full authority to implement the San Remo Decisions in Syria and to end the Faisal's adventure. The purpose of France in Syria is quite clear. In this case, where Britain would prefer to follow up quietly in the first stage, although Faisal would go to Europe against any military campaign of France and plan to take the support of Britain, the British Government would show its support to France by remaining silent for the implementation of the San Remo Decisions ${ }^{73}$. Faisal would first send Nuri Said to General Gouraud to prevent a military action and to ensure that France recognizes the independence of Syria under his kingdom. However, the general would reject this meeting and on July 14, on behalf of the French Administration, send an ultimatum to Faisal containing the French Government's requests. The General imposed conditions such as:

1. Acceptance of the French mandate government on Syria,

2. The granting of the Syrian railways to the French administration, the abandonment of Humus, Baalbek and Rayak Stations to the French Administration without resisting the occupation,

3. Turning over the leaders, who resist against the French and lead the national movement, to the French authorities,

4. The Syrian banknote to be based on the French Francs

5 . To reduce the number of soldiers by removing compulsory military service $^{74}$.

General Gouraud, who gave four days to Faisal to accept the abovementioned terms unconditionally, also told that he would resort to the use of force if no positive answer was given. Faisal first sent a representative to General Allenby, demanding his advice and support. However, Allenby withdrew his support from Faisal, saying that it was not possible for them to

\footnotetext{
${ }^{71}$ Fromkin, 2004, p. 375.

${ }^{72}$ Koloğlu, 2017, p. 339.

${ }^{73}$ Allawi, 2016, p. 349.

${ }^{74}$ Umar, 2014, p. 445.
} 
intervene. Failing to find the support of Britain, Faisal called the government to immediately convene a meeting and made it declared a state of emergency. The government also censored the press and took a series of urgent measures to equip the army. The Arab Administration in Damascus was preparing for war with France. But just as Faisal was left alone by the British, those in Syria, who could support him, had some hesitations about fighting against France. First of all, there were a large number of military experts who believed the Arab Army was inadequate in terms of ammunition and other equipment against the French Army, and Faisal was given the necessary briefings in this regard. However, there were also those who favored war $^{75}$. In such an atmosphere, Faisal secretly called the Syrian Congress to the meeting on July 17 and discussed issues of reconciliation or war with France. In this secret meeting, the majority of the members declared their views against the war with France, and the general tendency was towards the acceptance of General Gourand's ultimatum. The next day, Faisal gathered his cabinet to get a strong support at this point. In the meeting, a decision was made for the reconciliation with France instead of war and end all the preparations for war and this decision was conveyed to all the places where the army was deployed. At this point, the Arab Army was demobilized. On July 19, Faisal informed the French liaison officer in Damascus that the Syrian government had accepted the conditions of France ${ }^{76}$. In the meantime, some people from the Syrian Congress came together again and made the decision that the government accepting the French ultimatum would be considered illegitimate and published it in the official gazette, thus making it widely publicized ${ }^{77}$. With this decision, Faisal did not give up the acceptance of the ultimatum even though he thought that this would make him weaker against France. General Gouraud, however, did not stop proceeding, even though the Faisal government conveyed the decision before the deadline. This news led Faisal and his cabinet to a panic. Faisal gathered the people in the Umayyad Mosque and wanted them to defend their country by informing them about the general situation. Immediately afterward, a declaration was made and all the people were summoned to defend themselves against the French. Thereupon, the demobilized forces, together with the Arab forces that could join them, began to wait for the French Army in Maysalun. However, the Arabs had very little force because they were all not informed that the demobilization of the Arab Army was canceled. In addition, soldiers and officers from the Hijaz and other sections had also left the army ${ }^{78}$. After all, on July 24, at dawn, the

\footnotetext{
${ }^{75}$ Allawi, 2016, p. 349.

${ }^{76}$ Allawi, 2016, p. 353.

${ }^{77}$ Allawi, 2016, p. 353.

${ }^{78}$ Umar, 2014, p. 447.
} 
war broke out and by 10 o'clock the French forces began to move towards Damascus, destroying the remaining army of Faisal. The next day, while the French forces were on the way to Damascus, the General did not stop his progress, although Faisal still sent messengers to the general with the hope that he could agree with Gouraud. Then, Faisal desperately sent a telegram to Lord Curzon telling him that "because of his relationship with Britain, the French had taken revenge on him and that he wanted to be helped in such a situation...,79.

Faisal's telegram was showing the desperate situation he had fallen into. Although the British government had previously been appealed through Allenby, the English had been following the developments through Allenby, even though they had declared that they would not be involved in this issue. Hence, even the rumor that Sharif Hussein sent an army from Mecca to support Faisal was enough to bother Allenby in Cairo ${ }^{80}$. One day after Faisal's appeal to Lord Curzon, on July 27, General Gouraud sent to Faisal the following note: "I am honored to announce that the French Government wants you to leave Damascus with the Hijaz railway as soon as possible with your family and entourage. A special train will be at you and your entourage's service." Although Faisal rejected this note and retreated to Dera, the French threatened Faisal with the planes bombarding the region. In addition, with a notice to the public, Faisal and his wife was requested to be exiled from the city. Faisal, helplessly moved to Daya after he consulted his advisors and stop by Haifa on August 1. The English had wanted Faisal to come to Haifa. Thus, the eventful and stormy process that Faisal tried to establish an independent state for the Syrian Arabs came to an end in two and a half years ${ }^{81}$.

After the French forces entered Damascus, Faisal flew to Palestine, which was under the control of the English, and General Gouraud went to the tomb of Selahaddin Eyyubi in the Ancient City Center of Damascus and before the tomb of Selahaddin Eyyubi, he called on "Selahaddin, we returned", with a crusader mentality ${ }^{82}$.

After Syria's was conquered by the French and the elimination of Faisal's danger, the French government disintegrated Syria by dividing the country into administrative units in order to better manage it. With the declaration of General Gouraud on August 1, 1920, Lebanon was separated from Syria and recognized

\footnotetext{
${ }^{79}$ Umar, 1992, p. 450.

${ }^{80}$ FO. 371/5035, No: E- 4459, “From Lord Allenby to Lord Curzon”, May 1920.

${ }^{81}$ Allawi, 2016, p. 360.

${ }^{82}$ Burns, 1992, p. 91.
} 
as a state ${ }^{83}$. Then, separate states were established in the names of Alawite in Lazkiye and its vicinity, and Dürzî in Cebel-i Druz. The State of Aleppo was established in October 1920 and the State of Damascus was established in November 1920 by the French authorities. Then, the states of Damascus and Aleppo were reunited under the State of Syria. Under the Ankara Agreement signed with the Turkish Grand National Assembly in İskenderun Province, the autonomous İskenderun Province belonging to the Syrian State was established. The administrative structure on Syria has changed again in 1922, and the states within the Syrian borders were united under the Syrian Federation ${ }^{84}$. Despite all these administrative divisions, however, a general dissatisfaction with the French administration in general throughout Syria would continue in the following years. Thus, this dissatisfaction would manifest itself in the uprisings that put the French administration into trouble, as was between 1922 and $1925^{85}$.

\section{Cairo Conference and Faisal to Be the King of Iraq}

After the French forces entered Damascus and Faisal left Damascus and arrived in southern Palestine in the British administration, both Faisal's future and, -Iraq in particular-not being able to establish peace in many parts of the Middle East were continuing to occupy the London Government seriously. Estimating, more or less, the effects of the San Remo Decisions on the region, Lord Curzon wrote a review to the British Foreign Affairs when he was in Paris, in which he sought to determine how these decisions would be fully resolved with minimal damage in favor of England. In the review, Curzon stated that in no way they would not allow these events to affect the British presence in Palestine at the time when the French were preparing to identify Faisal as the king of Syria under their mandate and that they would not in any way recognize Faisal as the king of Palestine even under their mandate ${ }^{86}$. But it was more or less understandable with the course of the developments that this was the case. Allenby had repeatedly warned government officials in London, especially Curzon, about how dangerous Faisal might be before the Battle of Maysalun ${ }^{87}$.

While the British government was in a hurry to find a solution to the situation of Faisal when the French factor stepped in, it was constantly taking the views of the Middle East experts to observe the balance among the tribes in the Middle East, which was hanging on by a thread. The first thing that came to

\footnotetext{
${ }^{83}$ Fromkin 2004, p. 364; İskit 2017, p. 236.

${ }^{84}$ Umar 2014, p. 455.

${ }^{85}$ For more information on this subject, see. Arslan, 2014.

${ }^{86}$ FO. 371/5035, No: E 3810, "Cryptogram from Lord Curzon to the British Foreign Affairs", April 1920.

${ }^{87}$ FO. 371/5035, No: E 5905, “From Lord Allenby to Lord Curzon”, June 1920.
} 
mind in this particular was Lawrence's attitude. Coming up against the SykesPicot Treaty from the beginning, and believing that Britain should keep the promise given to the Arabs during the wartime, Lawrence was busy lobbying the government circles in London about that the best solution for Faisal was to offer him to be the king of Iraq.

However, since Abdullah, Sharif Hussein's other son, was promised the Iraqi kingdom, the question of how Abdullah would meet the new status of Faisal was now posing a problem. In addition, the questions of how would France react to Faisal to be the king of Iraq had not yet been answered. The British Government wanted to regain Faisal in some way and had received intelligence information that giving free rein to him would cause serious damage to the Allied interests in the Middle East. Indeed, the greatest concern in this regard was that Faisal could organize an Islamic Conference with his father by returning to Mecca and set his face against the British ${ }^{88}$. Faisal had begun lobbying to go to London to conduct negotiations again in recognition of the fact that the kingdom matter, which he thought was turning into a longwinded story, could only be solved by the English. However, in a meeting with the British high commissioners in Haifa, Faisal was allowed to go to Switzerland to meet with Lloyd George rather than London, according to reports from London. Since the British government was refraining from the direct reaction of the French government, such a move was considered appropriate for the time being. First, moving from Haifa with his entourage on August 18th to go to Italy, Faisal would stay in Naples for a while in order to see how the Arab case in Europe would take shape and decide the actions to be taken accordingly ${ }^{89}$. While he was in Naples, Faisal was woolly-headed and wondered what would happen to his new situation with British support on the one hand and on the other hand, he would not even neglect to make some attempts to contact the Kemalist Forces in an unrelenting struggle against the occupation forces in Anatolia. However, these attempts would remain inconclusive and Faisal would again be observing the attitudes of the London Government with a known policy ${ }^{90}$.

In the meantime, the group, especially Lawrence, who wanted Faisal to be the king of Iraq was working hard with government authorities in London. Especially after Churchill became the Minister of Colonies, these contacts became more frequent. First, Lawrence persuaded Lord Curzon to allow Faisal to come to London immediately, and it was announced that Faisal would be

\footnotetext{
88 İskit, 2017, p. 249.

${ }^{89}$ Allawi, 2016, p. 369.

${ }^{90}$ Musa, 1973, p. 150.
} 
hosted in London as the Hejaz representative to take over any French preclusion. So, Faisal came back to London in December 1920. With Faisal's arrival in London, the issue of Faisal becoming the king of Iraq had now reached the official contact levels, with already established contacts with Lord Curzon, Churchill, and many other influential people. In January 1921, this issue was now one of the most controversial issues of the British official circles. On January 10, Faisal was proposed kingdom at a meeting held in this context with the participation of Lawrence, William Ormsby-Gore and Walter Guinness $^{91}$. On February 14, 1921, when Churchill became the Minister of Colonies, the issue of Faisal's being the king of Iraq was immediately brought to the agenda of the ministry, and it was worked hard to solve the problem. For this purpose, a conference was decided to be held in Cairo by a Middle East specialists committee led by Lawrence ${ }^{92}$.

The conference in Cairo, with the main agenda of making a decision about Faisal to be the king of Iraq, began with the participation of forty people in total, including Churchill, Iraq High Commissioner Sir Percy Cox, Secretary of the Eastern Affairs and Cox's assistant, Gertrude Bell, and Lawrence, at Semiramis Hotel on 12 March 1921. In the first meeting, the statuses of the current candidates who were claimant to the Iraq throne were reviewed. Geylani, the ruler of the Iraqi government, Baghdad Nakib, the leader of the religious dynasty, Sayyid Talib of Basra, from effective political leaders, Sheikh Hazal bin Saud, the leader of the Muhammera region of southern Iran, Aga Khan and Burhanettin Efendi from the Ottoman dynasty were among the candidates. However, all of these candidates were seen by the high-level representatives participating in the conference as persons with deficiencies ${ }^{93}$.

Among the current candidates, Faisal to be enthroned was accepted during the first session of the conference and Lawrence notified the decision made to Faisal, who was in London at the time, without delay. Lawrence informed him that he was chosen as the king of Iraq by saying in the telegram he sent to Faisal, "... move on to Mecca in the shortest way without giving any information even to press". Despite this was the news that Faisal had been waiting for months, there was still a question of how his kingdom would be accepted by the people, especially by Abdullah, his older brother. But the British Administration would also find a solution to this by bringing Abdullah and Churchill together in Jerusalem, ensuring him to waive the Iraqi throne by

\footnotetext{
${ }^{91}$ Allawi, 2016, p. 393.

${ }^{92}$ Barr, 2016, p. 131.

${ }^{93}$ Allawi, 2016, p. 398.
} 
being the of King Mavera-i Jordan ${ }^{94}$. Thus, there was no obstacle, other than providing the so-called public support, on the way Faisal to be the king of Iraq. In the light of all these developments, the British Government would contact with the authorities in Iraq to bring Faisal to Baghdad with glorious ceremonies as soon as possible, and brought Faisal from Mecca to Basra. Faisal came to Basra in June with a modest welcome ceremony and visited Najaf, Kerbela, and Hilla in order to get the support of the people and to make an appearance after staying one day in the city. During his visit, Emir Faisal asked for support from the city's leading notables and tribal chiefs. In fact, as previously stated, all of these visits of Faisal were planned by the British authorities, and the English did not allow any negative situation on the way to Faisal's kingdom. Beside many officers and civil servants, especially Gertrude Bell from the British authorities, the public and the notables were ready to meet Faisal, who traveled by train from Hilla to Baghdad on June 29, at the Baghdad Station. The city was made ready for such a ceremony with the intense works which started days before. So much so that, in the letter he wrote to his father, Bell said would say, “... the whole city was ornamented, the triumphal arch and Arab flags were everywhere, the streets and the top of the houses were the crowds of people ... massive crowds in the station ..."

During the last days of June, when Faisal arrived in Baghdad, Iraq was prepared for a plebiscite to be made in July. This was necessary, even if it was faulty in terms of recognition of Faisal's kingdom - because no plebiscite could be applied in some cities. In conclusion, after receiving the popular support of the people after the plebiscite, Faisal ascended the throne in Baghdad on August 23, as the first king of Iraq in the English mandate, after a magnificent coronation ceremony. Thus, after his coronation ceremony, which Faisal expressed as "the rebirth of the Arabs", a new and irreversible process began in Iraq".

\section{Conclusion}

After the Ottoman Empire was defeated in the First World War, particularly the developments in Syria and Iraq in the period between 1918 and 1922, when reshaping of the Middle East was discussed (even realized) most

\footnotetext{
${ }^{94}$ In fact, Abdullah's abdication of the Iraqi throne had occurred under great pressure, and this had driven a wedge between Faisal and Abdullah. As in his mistakes in Syria, Faisal was criticized and accused also in this regard. But the British administration was persuading both Abdullah and his supporters who did not want Faisal to be the King with the threat that another person would be the king if Faisal was not king to Iraq. For more information, see. Allawi, 2016, pp. 399-404.

${ }^{95}$ Allawi, 2016, p. 443.

${ }^{96}$ Allawi, 2016, p. 443.
} 
intensively, created the preface of the recent history of the region. Although the nationalist events, which have escalated after the allied powers' decision to take these countries under the mandate regimes, were inspired by the National Struggle for Independence led by Mustafa Kemal in Anatolia, these events faced by the tough response of the allied powers and passed into the world history as the failed struggles. Although many arguments have been put forward to explain why these struggles failed, the influence of the fact that national identities cannot bring people living in both countries together at a common ideal point had a big influence on this result because of the strong tribal ties in the region. Furthermore, the fact that these two countries are largely influenced by external elements, such as England, rather than by their self caused them to be open to external intervention and, naturally, to have a constant controversy over their own territories.

It was believed that Sharif Hussein and his sons would rise against the Ottoman Empire in 1916 and declare their own kingdom in the Arab territories with an establishment supported by England. In fact, this belief was so strong that they had reacted against them by describing these initiatives of some Arab leaders as a betrayal. However, the fact that the British Government had given a promise to Sharif Hussein and shared the Arab territories with France on the one hand, and that the British Government undertook to give all kinds of support to the establishment of a Jewish State in Palestine with Balfour Declaration had disappointed Hussein and his sons. However, they had wanted to stay strictly adhered to the belief that the British Government would support them "under any circumstances". In fact, although Cemal Pasha informed Sharif Hussein of the existence of the Sykes-Picot Treaty, he always maintained his trust and loyalty of the British Government, and he had advised his son Faisal, who attended the Paris Peace Conference with the title of the President of Hedjaz Delegation, to be tied to the English officials' apron strings.

The fact that Faisal entered into negotiations in the Paris Peace Conference with the knowledge of the presence of the Sykes-Picot Treaty was disturbing the French Administration, which claimed right mostly in Syria. The French expressed that under no circumstances they wanted Faisal in Syria in any diplomatic environment to bring peace to the Middle East in the aftermath of the war. In such an environment, when the British Government was forced to make a choice between the two sides, all the promises made earlier were broken and the British took sides with the French in a network of relations, which became more complicated in the Middle East. But Faisal would have noticed this a bit late. So much so that when Clemenceau made a bargain with Lloyd George on Syrian in London, he would be aware of this long after the meeting between the two even though he was in London. The support of the British 
Government to Faisal against the French in Syria was going to be deceptive following the negotiations between Britain and France until the summer of 1920. In fact, the London Administration would not object to the expulsion of Faisal from Damascus after the Battle of Maysalun in July 1920. But with this new order in Palestine and Iraq, and the fear that it could bring harm to the order in the region which was already hanging on by a thread, the London Administration would not turn Faisal adrift, but enter into a search for a country where he could become king after the defeat of Damascus. 


\section{BIBLIOGRAPHY}

A- ARCHIVE DOCUMENTS

1-Public Record Office (National Archive of England)

DBFB 1919-1939- First Series, Volume 8, P. 95-104, No: 9.

DBFB 1919-1939- First Series, Volume 8, P. 95-108, No: 10.

FO. 608/92, No: 12033.

FO. 608/92, No: 6816.

FO. 608/92, No: 1694 .

FO. 608/92, No: 5700 .

FO. 608/92, No: 12032.

FO. 608/92, No: 13156.

FO. 608/92, No: 7864.

FO. 608/92, No: 14426.

FO. 371/ 5035, No: E 3810.

FO. 371/5035, No: E 4117.

FO. 371/5035, No: E 3965.

FO. 371/ 5035, No: E 4231.

FO. 371/5035, No: E 4698.

FO. 371/5035, No: E 5907.

FO. 371/5035, No: E- 5598.

FO. 371/5035, No: E- 4459.

FO. 371/5035, No: E 3810.

FO. 371/5035, No: E 5905.

\section{B-BOOKS}

Allawi 2014

Antonios 1989

Arslan 2014

Baytok, 2007

Barr 2016

Bell 2004

Bilgen 2004
Ali Allawi, Irak Kralı I. Faysal, Translated by Hakan Abacı, Türkiye İş Bankası Kültür Pbl., Istanbul.

George Antonios, The Arap Awakening, Khayal's Collage Book Cooperrive Beirut.

Emir Şekip Arslan, Translated by Muhammed Recai Gündüz, Şehit Suriye, Yarın Pbl, İstanbul.

Taner Baytok, Ingiliz Belgeleriyle Sevr'den Lozan'a, Dünden Bugüne Değişen Ne Var?, Doğan Kitap Pbl., İstanbul, 2007.

James Barr, Kırmızı Çizgi Paylaşılamayan Toprakların Yakın Tarihi, Translated by Ekin Can Göksoy, Pegasus Pbl., Istanbul. Gertrude L. Bell, Mezopotamya'da 1915-1920 Sivil Yönetimi, Translated by Vedii İlmen, Yaba Pbl., Istanbul.

Deniz Bilgen, ABD’li Gözüyle Sivas Kongresi Amerikan Mandasi ve Gazeteci L.E. Browne'nin Faaliyetleri, Kaynak Pbl., İstanbul. 
Burns 1992

Evans 2003

Formkin 2004

Görün 1986

Grainger 2015

Haydar 1988

Helmreich 1996

İskit 2017

Karakaya 2001

Köse 2014

Koloğlu 1994

Koloğlu 2017

Lansing 1922

Lazarev 1989

Macmillan 2004

Musa 1973

Olcay 1981

Öke 2011a

Öke 1999
Ross Burns, The Monumets of Syria, Londra.

Laurance Evans Türkiye'nin Parçalanması ve ABD Politikaları (1914-1924), Örgün Pbl, İstanbul.

David Fromkin, Barışa Son Veren Barış, Modern Ortadoğu Nasıl Yaratıldı? (1914-1922), Translated by Mehmet Harmanc1, $4^{\text {th }}$ Edition, Epsilon Pbl. Istanbul.

Kamuran Görün, Savaşan Dünya ve Türkiye, Bilgi Pbl., Ankara.

John D. Grainger, Suriye İçin Savaş 1918-1920, Translated by Özer Bostanoğlu, Tarih\&KuramPbl., Istanbul.

Rüstem Haydar, Mudhakarrat Rüstem Haydar, Ed. Nejat Fathi Safwat, Al Dar- al- Arabiyalil Mawsou'at Bayrut.

Paul, C. Helmreich, Sevr Entrikaları, Büyük Güçler, Maşalar,

Gizli Antlaşmalar ve Türkiye'nin Taksimi, Translated by Şerif Erol, Sabah Pbl., İstanbul.

Temel İskit, Diplomasinin Gücü Modern Ortadoğu'nun Şekillenmesi, İstanbul Bilgi Üniversity Pbl, İstanbul.

Ali Karakaya Milli Mücadele'de Manda Sorunu ve Harbold ve King-Crane Heyetleri, Başkent Pbl., Ankara.

İsmail Köse, Ingiliz Arşiv Belgelerinde Hicaz İsyanı, Selis Pbl., İstanbul.

Orhan Koloğlu, Gazi'nin Çă̆ında İslam Dünyası, Boyut Pbl., İstanbul.

Orhan Koloğlu, Türk-Arap İlişkileri, $2^{\text {nd }}$ Edition, Tarihçi Kitapevi, İstanbul.

Robert Lansing, The Big Four and Others of The Peace Conferance, Hutchinton, Londra.

M. S. Lazarev, Emperyalizm ve Kürt Sorunu (1917-1923), Translated by. Mehmet Demir, Öz-ge Pbl., Ankara.

Margaret Macmillan Paris 1919, 1919 Paris Barış Konferansı ve Dünyayı Değiştiren Altı Ayın Hikâyesi, Translated by Belkıs Dışbudak, ODTÜ Pbl., Ankara.

Süleyman Musa, Al-Murasalat al- Tarikhiya, 1918-1914, V. I, Amman.

Osman Olcay, Sevres Barış Antlaşmasına Doğru (Çeşitli Konferans veToplantıların Tutanakları ve Bunlara İlişkin Belgeler), AÜSBF Pbl. Ankara, 1981.

Mim Kemal Öke, Siyonizm ve Filistin Sorunu (1880-1913), Kırmızıkedi Pbl., İstanbul.

Mim Kemal Öke, Mustafa Kemal Paşa ve İslam Dünyası Hilafet Hareketi, Aksoy Pbl., $2^{\text {nd }}$ Edition, İstanbul. 
Öke 1992

Satan 2016

Schneer 2011

Uçarol 1995

Umar 2014
Mim Kemal Öke, Belgelerle Türk- Ingiliz İlişkilerinde Musul ve Kürdistan Sorunu (1918-1926), Türk Kültürü Araştırma Enstitüsü Pbl., Ankara.

Ali Satan, Irak'ta İngiliz İşgal Yönetimi (1914-1918) İngiliz Devlet Arşivi Raporu, Translated by. Nilgün Engin, Tarihçi Kitapevi, İstanbul.

Jonathan Schneer, Balfour Deklarasyonu, Translated by. Ali Cevat Akkoyunlu, Kırmızıkedi Pbl., İstanbul.

Rıfat Uçarol, Siyasi Tarih (1789-1994), $4^{\text {th }}$ Edition, Filiz Kitapevi, İstanbul.

Ömer Osman Umar, Osmanlı Yönetimi ve Fransız Mandası Alttnda Suriye (1918-1938), AAM Yay., Ankara.

\section{C- DISSERTATIONS}

Kılınçkaya 1992 Mehmet Derviş Kılıçkaya, Arap Milliyetçiliği ve Milli Mücadele'de Türkiye- Suriye Ilişkileri (30 Ekim 1918- 21 Temmuz 1921), (Unpublished PhD Thesis), Hacettepe University, Institute for Ataturk's Principles and Reforms, Ankara.

Yavuz 2016

Resul Yavuz, Mondros Ateşkes Antlaşması'ndan Sevr Barlş Antlaşması'na Giden Süreçte Türk Diplomasisi, Dokuz Eylül University, (Unpublished PhD Thesis), Izmir. 